\title{
Peran Perempuan Dalam Wilayah Publik
}

(Analisis Hadits Hadis Riwayat Bukhari Nomor 4037 dengan Pendekatan sosio-Historis-Kontekstual)

\author{
Muhammad Nasir \\ Dosen STAIN Majene \\ muhnasirochastainmajene.ac.id
}

Sartina

(Mahasiswa Prodi Ilmu al-Qur'an dan Tafsir STAIN Majene)

\begin{abstract}
Abstrak
Fokus kajian ini yaitu peran perempuan dalam wilayah publik dalam tinjauan hadis, yang sering dipahami secara berbeda oleh para ulama dalam memahaminya. Kajian ini disajikan untuk memahami dasar para ulama dalam memahami hadis yang menimbulkan perbedaan di antara mereka. Hadis pada tulisan ini menggunakan metode tahlili dengan pendekatan sosio-historis kontekstual. Hasil dari pembahasan ini ditemukan bahwa hadis riwayat Bukhari tersebut kualitasnya shahih, sedangkan pemahaman dari hadis itu memunculkan dua pendapat yaitu kelompok konservatif yang memahami hadis secara tekstual sehingga perempuan tidak boleh menjadi pemimpin, dan kelompok liberal progresif yang memahami hadis secara kontekstual dan memahami bahwa perempuan dapat mengambil peran dalam wilayah publik termasuk untuk menjadi pemimpin, karena apa yang disampaikan Nabi dalam hadis tersebut sifatnya kasuistik.
\end{abstract}

Kata Kunci: Peran Perempuan, Hadis, wilayah publik, kontekstual.

\section{A. Pendahuluan}

Diskursus tentang gender menjadi isu yang tidak pernah selesai dikaji oleh para ilmuan karena lingkup bahasannya dapat menembus sekat-sekat birokrasi, perguruan tinggi, dan rumah tangga. Namun, perbedaan pemahaman tentang apa yang dimaksud dengan gender dan kaitannya dengan perempuan masih menjadi perdebatan yang cukup alot. Istilah gender seringkali dikacaukan dengan istilah jenis kelamin yang menunjuk kepada jenis kelamin perempuan.

Gender merupakan konsep yang menunjuk pada peran-peran dan tanggung jawab laki-laki dan perempuan sebagai hasil konstruksi sosial yang dapat diubah sesuai dengan perubahan zaman. Realita saat ini dapat terlihat bagaimana peranan wanita yang memperjuangkan hak-hak dan menuntut persamaan, setelah balajar 
dari pengalaman dimasa yang lalu, dimana wanita sangat tersudutkan atau termarjinalkan.

Dalam ajaran Islam, Al-Qur'an sebagai rujukan prinsip dasar masyarakat Islam menunjukkan bahwa pada dasarnya mengakui bahwa kedudukan laki-laki dan perempuan adalah adil. ${ }^{1}$ Keduanya diciptakan dari satu "nafs" (living entity), dimana yang satu tidak memiliki keunggulan terhadap lain, ${ }^{2}$ bahkan salah satu tema utama sekaligus prinsip pokok dalam ajaran Islam adalah persamaan antara manusia, baik antara laki-laki dan perempuan maupun antar bangsa, suku dan keturunan. ${ }^{3}$ Perbedaan yang digarisbawahi dan yang meninggikan atau merendahkan seseorang hanyalah nilai pengabdian dan ketakwaannya kepada Tuhan Yang maha Esa. ${ }^{4}$

Apa yang dicita-citakan al-Qur'an tidaklah sebagaimana diduga atau dipraktekkan sementara masyarakat. Bahkan pandangan masyarakat terhadap perempuan sebagai makhluk yang memiliki derajat di bawah laki-laki seringkali didasarkan pada ajaran agama. Tafsiran keagamaan yang bias gender disebabkan oleh faktor kedangkalan pengetahuan keagamaan terutama pada pemahaman ajaran-ajaran agama yang bersumber dari hadis-hadis yang dikategorikan oleh kelompok feminis sebagai hadis-hadis "misoginis". 5

Berkaitan dengan hal tersebut, terdapat keterangan hadits nabi yang cukup populer yang melarang seorang wanita untuk menjadi pemimpin. Hadis ini kemudian menjadi rujukan bagi kelompok yang senantiasa mendiskreditkan

\footnotetext{
${ }^{1}$ QS. An-Nisa: 1

${ }^{2}$ Mansour Fakih dkk, Membincang Feminisme Diskursus Gender Perspektif Islam, (Surabaya: Risalah Gusti, 1996), h. 50.

${ }^{3}$ M. Quraish Shihab, Membumikan al-Qur'an, (Bandung: Mizan, 2004), h. 269

${ }^{4}$ QS. Al-Hujurat (49):3

${ }^{5}$ Istilah misoginis berasal dari bahasa Inggris dengan kata "misogyny" yang berarti "kebencian terhadap wanita". Namun secara terminologi istilah misoginis juga digunakan untuk doktrin-doktrin sebuah aliran pemikiran yang secara zahir memojokkan dan merendahkan derajat perempuan, seperti yang terdapat dalam beberapa teks hadis. Euis Daryati, Menjawab Tafsir Misoginis. http://quran.al-shia.org/id/tafsir/01/01.html
} 
perempuan dalam mengambil peran dalam ranah publik dan menjadi senjata untuk memarjinalkan perempuan ketika ada mement-moment tertentu bagi perempuan untuk menyatakan eksistensi dirinya untuk menjadi pemimpin dalam suatu komunitas atau organisasi tertentu.

Hadits inilah yang akan dibahas dalam tulisan ini, dengan menggunakan pendekatan historis, sosiologis dan antropologis, dengan harapan dapat memberikan pemahaman hadits yang lebih tepat, apresiatif dan akomodatif terhadap perubahan dan perkembangan zaman. Sehingga dalam memahami suatu hadits tidak hanya terpaku pada teks saja, tetapi harus juga memperhatikan kondisi saat itu. Hal ini berangkat dari asumsi dasar bahwa ketika Nabi bersabda beliau tidak lepas dari kondisi yang melingkup masyarakat pada waktu itu atau mustahil Nabi bicara dalam ruang yang hampa sejarah. Bagaimanapun sebuah gagasan atau ide termasuk dalam hal ini sabda Nabi selalu didasarkan dengan masalah sejarah, yakni problem yang terkait dengan historis kultural waktu itu.

\section{B. Pembahasan}

\section{a. Pengertian Gender}

Asal kata gender merupakan bahasa Prancis pertengahan 'gendre' kemudian kata tersebut dilacak dan diidentifikasi sebagai bahasa Latin 'genus' yang bermakna "jenis" atau "tipe", dan dalam bahasa Prancis modern kata genre dikaitkan dengan genre sexual. Dalam kamus Oxford English Dictionary tahun 1900 disebutkan bahwa arti pada awalnya gender diartikan "jenis". 6

Gender secara bahasa dapat diartikan jenis kelamin. Dalam kamus Webster's New World Dictionary gender diartikan sebagai diperensiasi antara laki-laki dan perempuan dengan melihat nilai dan tingkahl laku. Sedangkan dalam ensiklopedi Women's studies, gender adalah perbedaan laki-laki dan perempuan

\footnotetext{
${ }^{6}$ https://id.wikipedia.org/wiki/Gender di akses pada tanggal 20 februari
} 2020. 
dalam hal prilaku, mentalitas, peran dan karakteristik emosi dalam kehidupan bermasyarakat. ${ }^{7}$

Berdasarkan pengertian gender di atas, dapat disimpulkan bahwa gender adalah perbedaan antara laki-laki dan perempuan dalam sikap dan peran mereka baik dalam lingkup domestik rumah tangga maupun dalam lingkup publik, bukan perbedaan jenis kelamin dari aspek biologis, tetapi jenis kelamin sosiologis yang lebih kepada fungsi dan peran antara laki-laki dan perempuan.

\section{b. Analisis Hadis Kepemimpinan Wanita dalam Wilayah Publik}

Fokus kajian hadits yang diteliti yaitu hadis riwayat al-Bukhari no. 4073 tentang larangan wanita menjadi pemimpin sebagaimana teks hadis di bawah ini:

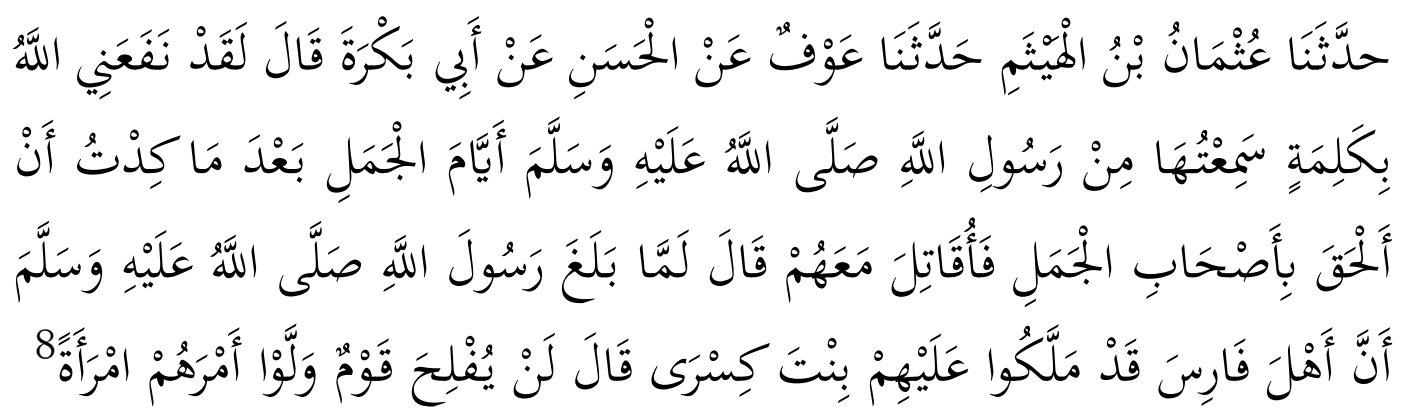

Dari aspek keshahihan sanad hadis riwayat al-Bukhari di atas, secara kualitas dinilai shahih, selain tingkatan riwayat al-Bukhari yang diakui sebagai periwayat hadis yang paling terpercaya, periwayatnya juga bersambung. Di antara alasannya karena tempat tinggal para periwayat di atas, semuanya tinggal di Bashrah sehingga bisa diyakini bahwa perawi hadis betul-betul bertemu.

\footnotetext{
${ }^{7}$ Nasaruddin Umar, Argumen Kesetaraan Gender Perspektif alQur`an, Jakarta: Paramadina, 2001, h. 33

8 Abu Abdullah Muhammad ibn Isma il ibn Ibrahim al-Bukhariy, Shahih al-Bukhari, Kitab al-Magazi, (CD Mausuah al-Hadis al-Syarif) no. 4073, kitab fitn, no. 6570; lihat juga HR. Al-Tirmidzi, Sunan al-Tirmidzi, kitab al-fitn 'an al-rasul. No. 2188; H.R. al-Nasa'i, Sunan al-Nasa'i, Kitab Adab al-Qadha', no. 5293; H.R. Ahmad bin Hanbal, Musnad Ahmad bin Hanbal, awwal al-Musnad al-Basriyyin, nomor 19507, 19573 dan 19612.
} 
Pada periwatan hadits ini, dapat dilihat bahwa Abu Bakrah yang berada pada thabaqat sahabat, yang mendengar langsung sabda Nabi di atas, sendiri dalam periwayatan. Hadits ini termasuk hadits ahad, karena hadits tersebut diriwayatkan dari nabi oleh perawi yang jumlahnya tidak mencapai jumlah perawi hadits mutawatir, hal inilah yan banyak dikritik oleh para ilmuan modern terutama mengenai ihwal Abu Bakrah.

Bukhari tidak menjelaskan lebih jauh perihal kehidupan Abu Bakrah, dia hanya menukil matan hadits yang diriwayatkan oleh Abu Bakrah tersebut. ${ }^{9}$ Mengenai perihal Abu Bakrah dijelaskan dalam kitab Fath al-Bari yang mensyarah semua hadits yang terdapat dalam kitab Jami al-Shahih, dengan mengungkap kesejarahan, peristiwa-peristiwa politik yang menjadi latar belakang, gambaran tentang pertempuran-pertempuran, identitas dari kelompok-kelompok yang bertentangan, identitas dari para perawi dan pandangan-pandangan mereka.

Sebelum masuk Islam, Abu Bakrah mengalami kehidupan yang berat, kehidupan hina sebagai seorang budak di kota Thaif. Pada saat itu, hanya golongan bangsawan yang memiliki hak untuk menduduki jabatan tinggi. Abu Bakrah masuk Islam setelah Nabi menyeru penduduk Thaif untuk bergabung dengan pasukannya walaupun dia seorang budak. Puluhan budak menyambut seruan tersebut dan Abu Bakrah termasuk di dalamnya, dan Rasulullah menyatakan mereka sebagai orang yang merdeka. ${ }^{10}$

Ketika tugas untuk membuat riwayat hidup para sahabat telah dimulai, beberapa ahli berada dalam kesulitan karena paternalitas (Kedudukan seorang ayah) Abu Bakrah tidak menentu. Imam ibnu Hanbal yang melakukan penelitian terhadap garis keturunan para sahabat, mengakui harus melewati secara cepat terhadap kasus Abu Bakrah tanpa memberikan rincian, karena dia dianjurkan untuk tidak menyelaminya terlalu dalam karena sulit dilacak dengan tidak

\footnotetext{
${ }^{9}$ Fatima Mernissi, Menengok Kontroversi peran Wanita dalam Politik, Terj. Oleh Masyhur Abadi (Cet, I, Surabaya: Dunia Ilmu, 1997), h. 55.

${ }^{10}$ Ibn Saad, Thabaqat, Jilid 3, h. 159.
} 
memiliki garis keturunan yang masyhur. ${ }^{11}$ Ketidak jelasan paternalitas inilah yang mengakibatkan kritik yang dilontakan oleh ilmuan khusunya para pejuang hak-hak wanita.

Kasus lain mengenai Abu Bakrah adalah dia pernah dihukum cambuk karena telah memberikan tuduhan palsu. Dia dan tiga orang sahabatnya melemparkan tuduhan resmi tentang perbuatan Zina kepada seorang yang sangat terkenal yaitu al-Mudhira Syubah. Kesaksian mereka diselidiki oleh Umar bin Khattab, dan salah seorang dari mereka mengakui tidak yakin telah melihat segala sesuatunya. Keraguan dari salah satu saksi tersebut menjadikan saksi-saksi lain dihukum cambuk. $^{12}$

Abu Bakrah sendiri menurut Fatima Mernissi, pada mulanya dia memang seorang sahabat yang baik dan setia, Suatu ketika dia dihadapkan pada persoalan dilematis ketika terjadi konflik antara Ali dan Aisyah, dalam memperebutkan Bashrah. Dia harus memilih apakah berada dibelakang barisan Ali, berarti melawan janda Rasulullah, atau berada dibelakang barisan Aisyah yang berarti melawan menantu Rasulullah. Abu Bakrah akhirnya memilih untuk tidak berpihak kepada salah satunya, namun, setelah kekalahan Aisyah pada perang jamal, tibatiba dia menggali hadits yang 25 tahun telah terpendam dalam ingatannya dalam situasi dan konteks yang berbeda. ${ }^{13}$

\section{c. Asbab al-Wurud Hadis}

Adapun asbab al-wurud hadits di atas, diucapkan Nabi sewaktu beliau mendengar laporan mengenai suksesi kepemimpinan wanita di Negeri Persia pada tahun ke $9 \mathrm{H}$. Menurut tradisi yang berlaku di Persia sebelum itu, yang diangkat sebagai kepala negara adalah seorang laki-laki. Sedangkan pada tahun $9 \mathrm{H}$, yang

${ }^{11}$ Ibnu al-Athi, Usd al-Ghaba fi Tamyis al-Sahabah,jilid 5, (Dar al-Fikr li al-Tiba wa al-Tawzi, t.th.), h. 159

${ }^{12}$ Fatimah Mernissi, Menengok Kontroversi peran Wanita dalam Politik, h. 73.

${ }^{13}$ Fatimah Mernissi, Menengok Kontroversi peran Wanita dalam Politik, h. $59-61$. 
terjadi justru menyalahi teradisi biasanya, yakni mengangkat kepala negara seorang wanita yang bernama Buwaran binti Syairawaihi bin Kisra bin Barwaiz. Dia diangkat menjadi ratu Persia karena saudara laki-lakinya terbunuh sewaktu melakukan perebutan kekuasaan. ${ }^{14}$

Dalam kondisi sosio-historis semacam inilah Nabi sebagai orang yang memiliki kearifan menyatakan bahwa bangsa yang menyerahkan kepemimpinannya kepada wanita tidak akan sukses, jika pemimpinannya saja adalah seorang yang tidak dihargai oleh masyarakatnya. Padahal salah satu syarat ideal seorang pemimpin adalah kewibawaan, disamping mempunyai leadhersip yang memadai. Sementara wanita saat dipandang tidak mempunyai leadhersip dan kewibawaan untuk menjadi pemimpin masyarakat. ${ }^{15}$

\section{d. Analisa Matan Hadits dan Pro Kontra Ulama}

\section{Kelompok Konservatif}

Hadits di atas berkenaan dengan suatu kasus tertentu, sebagaimana yang terlihat dalam asbab al-wurud di atas, yaitu mengenai putri Persia yang diangkat menjadi kepala negara. Hadits ini khusus berkenaan dengan bangsa Persia karena tidak ada laki-laki yang bisa diangkat menjadi raja. Selain itu, hadits inipun berkenaan dengan jawaban Allah terhadap doa Nabi ketika Kisra menyobek surat beliau yang dikirim kepadanya. Ketika itu Nabi berdoa kepada Allah agar Dia mengahancurkan kerajaan itu. Maka Allah mengabulkan doanya. Oleh karena itu, hadits tersebut hanya berlaku secara khusus, tidak berlaku umum. ${ }^{16}$

Hadits tersebut secara tekstual, memberikan isyarat bahwa wanita tidak berhak menjabat sebagai kepala negara, pemimpin masyarakat, termasuk hakim atau berbagai jabatan yang setingkat. Demikianlah pendapat yang diikuti Jumhur

\footnotetext{
${ }^{14}$ Ibnu Hajar al-Asqalani, Fath al-Bari, Juz VIII, (Cet. I, Kairo: Dar alHadits, 1998), h. 128.

${ }^{15}$ Syuhudi Ismail, Hadits Nabi yang Tekstual dan Kontekstual, (Cet. I, Jakarta: Bulan Bintang, 1994), h. 66.

${ }^{16}$ Muhammad Anis Qasim Ja'far, Perempuan dan Kekuasaan, terj. Irwan Kurniawan et.al., (Cet. I, Bandung: Zaman Wacana Islam, 1998), h. 49.
} 
Ulama. Karena menurut mereka berdasarkan hadits tersebut, persyaratan khalifah antara lain al-Dzukarahyakni sifat laki-laki. Al-Kahttabi yang dikutip dalam Kitab Fath al-Bari misalnya berpandapat bahwa wanita tidak sah menjadi Khalifah. ${ }^{17}$ Demikian juga al-Syaukani ${ }^{18}$ dalam memahami hadits ini, dia berpendapat bahwa wanita tidak termasuk ahli dalam hal kepemimpinan, sehingga ia tidak boleh menjadi kepala negara. ${ }^{19}$

Pendapat Al-Qalqasyandi yang dikutip Oleh Syafiq Hasyim menyatakan bahwa perempuan dilarang menjadi kepala pemerintahan karena dia memiliki kekurangan dalam dirinya. Kekurangan tersebut menyebabkan perempuan tidak mampu mangawinkan dirinya sendiri, apalagi perwalian atas orang lain. ${ }^{20}$ Kelompok yang mendukung hadits di atas juga berpendapat bahwa dalam agama Islam, Dunia peran dibagi dalam dua bagian yaitu, Wilayah Publik dan wilayah domestik. Wilayah publik meliputi urusan-urusan sosial kemasyarakatan, seperti penyusunan undang-undang, melakukan proses rekonsiliasi terhadap konflikkonflik yang terjadi dalam masyarakat umum, menjalankan pemerintahan dan lainlain. Dan wilayah khusus meliputi tugas-tugas rumah tangga, mendidik anak, dan tugas-tugas lain yang bersifat internal. ${ }^{21}$

Dari pendapat di atas, dapat diketahui bahwa Islam telah menentukan peran perempuan dalam wilayah domestik. Secara Historis sejak kelahiran, Islam tidak pernah menyandarkan urusan publik kepundak perempuan. Sejak masa

\footnotetext{
${ }^{17}$ Ibnu Hajar al-Asqalani, Fath al-Bari, h. 128.

al-Imam Muhammad bin Ali bin Abdullah al-Syaukani, lahir pada tahun $1173 \mathrm{H}$, di negeri Syaukan dan di besarkan di San'a dan wafat pada tahun $1250 \mathrm{H}$. di antara karya beliau adalah Nail al-Authar Syarh itab Muntaqa al-Akhbar, Irsyad al-Tsiqat ila Ittihaf al-Syara'l 'ala al-Tauhid wa alMa'adi wa al-Nubuwat, dan al-Qaul al-Mufid fi Adillah al-Ititihadi wa al-Taqlid. Lihat al-Syaukâni, Nail al-Authar Syarh kitab Muntaqa al-Akhba. Beirut: Dâr al-Fikr. T.th. Mukaddimah.

${ }^{19}$ Muhammad Ibnu Ali Ibnu Hajar al-Asqalani, Nail al-Authar, Jilid VII, (Beirut: Dar al-Fikr, t.th.), 298,

${ }^{20}$ Syafiq Hasyim, Hal-hal yang Tak Terpikirkan tentang isu-isu keperempuanan dalam Islam, (Cet. II, Bandung: Mizan, 2001)h. 191.

${ }^{21}$ Ibid.
} 
kenabian, tak seorangpun perempuan yang turut terlibat secara langsung dalam kegiatan politik.

Ada juga yang berpendapat bahwa perempuan tidak boleh menjadi kepala negara karena perempuan berbeda dengan laki-laki dari sudut biologis, rasionalitas, serta peradabannya. Perempuan dari sudut biologis merupakan makhluk lemah. Dari sudut rasionalitas, kelompok ini mengaggap bahwa kaum perempuan pada umumnya cenderung lebih mendahulukan emosi dan perasaannya daripada nalarnya. Kemudian dari sudut perkembangan perdaban, tampak sejarah umat manusia, andil dan sumbangsih kaum perempuan dalam membangun peradaban tidak begitu terlihat. ${ }^{22}$

Pendapat lain juga mengatakan bahwa pemisahan laki-laki dan perempuan merupakan persoalan yang sangat penting. Bagaimanapun perempuan tidak sama dengan laki-laki, karena berbeda dalam susunan otak dan jiwanya. Perempuan seringkali tidak bisa bertahan manakala dikejutkan dengan satu peristiwa. Perempuan juga tidak akan bertahan lama ketika harus berada di medan perang. Sementara urusan perang, mengadakan perjanjian dan mengadakan perdamaian membutuhkan kekuatan mental, kestabilan emosi, keberanian dan keteguhan untuk tetap bertahan yang kesemuanya ini tidak dimiliki perempuan. ${ }^{23}$

Lebih lanjut dikatakan bahwa bila selama ini terdengar adanya penguasa perempuan, mereka itu bukanlah penguasa yang sesungguhnya, mereka hanyalah perempuan yang memiliki kemampuan menguasai teori-teori kepemimpinan. Mereka menjadi berwibawa karena keberhasilan mereka menguasai laki-laki yang lemah. ${ }^{24}$ Pendapat ini dapat dipahami bahwa pemimpin harus dari laki-laki dengan

\footnotetext{
${ }^{22}$ Syafiq Hasyim, Hal-hal yang Tak Terpikirkan tentang isu-isu keperempuanan dalam Islam, h. 195-196.

${ }^{23} \mathrm{Abdu}$ al-Rasu,Abdul Hasan al-Ghafar, Wanita dan gaya hidup Modern, (Jakarta: Pustaka Hidayah, 1994), h. 160.

${ }^{24} \mathrm{Abdu}$ al-Rasu,Abdul Hasan al-Ghafar, Wanita dan gaya hidup Modern, h. 160.
} 
melihat kondisi fisik yang lebih kuat bila dibandingkan kondisi fisik seorang wanita yang sudah menjadi kodratnya dan tidak bisa ditawar-tawar.

Dari hadits ini, dapat diketahui bahwa perempuan tidak boleh menduduki jabatan umum apapun, sebab tidak ada kemenangan dan kesuksesan. Maka dalam kemenangannya pun ada kerugian. Kerugian itu harus dihindari. Mereka merujukkan larangan ini pada emosi perempuan dan sifat-sifat kodratnya yang menjadikannya tidak mampu mengambil keputusan yang benar. Pendapat inipun menambahkan larangan yang terkandung dalam hadits yang melarang setiap perempuan pada masa kapanpun untuk menduduki jabatan kepentingan umum. Keumuman ini dipahami dari konteks dan gaya ungkapan hadits tersebut, sebagaimana dipahami makna larangan yang dikandung dalam hadits tersebut.

\section{Kelompok Liberal-Progresif}

Berseberangan dengan kelompok pertama (konservatif), kelompok ulama yang lebih cenderung liberal-progresif tidak menghalangi perempuan terlibat dalam dunia politik. Secara eksplisit kelompok ini menyatakan bahwa perempuan memiliki hak penuh untuk berpolitik. Kaum perempuan juga diizinkan memangku tugas-tugas politik seberat yang dipangku oleh laki-laki.

Kelompok ini berpendapat bahwa hadits di atas adalah hadits ahad. Hadits ahad tidak mendatangkan keyakinan melainkan hanya mendatangkan dugaan kuat (Zhan) saja. Oleh karena itu tidak boleh bersandar pada hadits ahad dalam hukumhukum yang sangat penting. Terlebih lagi partisipasi perempuan dalam hak-hak politik yang dianggap sebagai masalah yang memiliki landasan konstitusional yang mencakup larangan kepentingan. Sebab hal itu, berkaitan dengan sistem pemerintahan serta hak-hak dan kebebasan individu. Dalam hal ini kita tidak boleh berargumen dengan dalil zhanni, bukan yakini. ${ }^{25}$

${ }^{25}$ Muhammad Anis Qasim Ja'far, Perempuan dan Kekuasaan, h. 50. 
Di antara sekian banyak hadits, ada yang hukumnya berlaku secara umum dan ada pula yang berlaku sementara atau dalam jangka waktu tertentu. Berkaitan dengan itu, hadits di atas tidak memiliki keumuman. Selain itu, hadits-hadits juga ada yang berasal dari Rasulullah dalam kapasitasnya sebagai seorang pemimpin dan hakim seluruh kaum muslimin. Maka hadits ini tidak termasuk landasan hukum yang bersifat umum, sebab hadits-hadits itu didasarkan pada kepentingan yang muncul pada masa tertentu saja. Oleh karena itu, tidak menjadi keharusan bagi kita berpegang pada hadits-hadits tersebut karena bersumber dari Rasulullah dalam kapasitasnya sebagai pembawa kabar gembira saja, bukan sebagai Rasul. ${ }^{26}$

Tentang perempuan sebagai pemimpin negara memang sering dipahami secara subjektif dan hitam putih. Misalnya ketika Benazir Bhutto naik menjadi perdana menteri Pakistan, banyak ulama di sana yang mengecam kedudukannya. Oleh karena itu, ketika Benazir Bhuto berhasil digulingkan, kelompok fundamentalis menjadikan hal tersebut sebagai sasaran untuk menyerang kemampuan perempuan dalam memegang tampuk kepemimpinan. ${ }^{27}$ Mengapa setiap kekalahan perempuan dalam pentas politik selalu dikaitkan dengan citra kelemahan kepemimpinan perempuan secara general dan langsung menjadikannya sebagai bukti abadi. Padahal, kalau terjadi sebaliknya, umpamanya seorang kepala negara laki-laki yang gagal, masyarakat mengemontari sebagai hal yang biasa saja.

Demikian juga dalam hadits di atas, Abu Bakrah mengingat kembali hadits yang sudah 25 tahun setelah kematian Rasulullah diungkap kembali olehnya setelah Aisyah mengalami kekalahan pada saat perang jamal. Aisyah termasuk wanita pertama yang melanggar batas antara wilayah kaum wanita dan wilayah kaum pria, yang terjun kemedan perang. Dia mengambil keputusan politik dengan memimpin orang-orang bersenjata. Aisyah melakukan kampanye untuk merekrut para pendukung, terutama dikalangan sahabat Nabi yang memegang kekuasaan untuk membuat keputusan sebagai para gubernur propinsi dan dengan demikian

\footnotetext{
${ }^{26}$ Muhammad Anis Qasim Ja'far, Perempuan dan Kekuasaan, h. 50.

${ }^{27}$ Syafiq Hasyim, Hal-hal yang Tak Terpikirkan tentang isu-isu keperempuanan dalam Islam h. 200.
} 
dapat membantunya untuk membangun pasukan. Namun, mereka berargumen dengan menolak inisiatifnya dan memutuskan untuk tetap setia kepada khalifah Ali. Mereka tidak pernah berargumen yang didasarkan atas kecakapannya dan keintelektualannya.

Kegagalan kepemimpinan pada dasarnya tidak bisa disandarkan pada diri pribadi sang pemimpin saja. Apalagi dalam sistem kepemimpinan modern yang sudah tidak bergantung lagi kepada kemampuan personal individu, keberhasilan atau kegagalan merupakan tanggung jawab kolektif orang yang terlibat dalam sistem kepemimipinan tersebut.

Dalam teori manajemen modern, seorang pemimpin adalah orang yang mampu mengorganisasikan semua elemen yang terdapat dalam lingkup manajemen. Di sana ada manusia, asset, pasar dan unsur-unsur pendukung lainnya. Seorang pemimpin negara yang berhasil adalah pemimpin yang mampu menggunakan elemen-elemen di atas secara efektif. ${ }^{28}$ Apabila Perempuan memang mampu mengelola unsur-unsur manajemen secara baik, mengapa perempuan tidak boleh menjadi kepala negara?

Dengan melihat kembali asbab al-wurud hadits di atas, pada waktu itu derajat kaum wanita di mata masyarakat masih dipandang minor. Wanita tidak dipercaya untuk mengurus masalah publik lebih lebih masalah kenegaraan. Pandangan semacam ini, jika dikaitkan dengan kondisi ketika itu sangat logis, sebab wanita saat itu masih tertutup, sehingga wawasan dan pengetahuannya juga relatif kurang dibanding laki-laki. Seakan-akan hanya laki-lakilah yang cakap memimpin. Keadaan seperti itu tidak hanya terjadi di Persia saja, tetapi juga di Jazirah Arab dan lain-lain. ${ }^{29}$ Kemudian Islam datang mengubah Nasib wanita. Mereka diberi hak, kehormatan dan kewajiban oleh Islam sesuai dengan harkat dan

\footnotetext{
${ }^{28}$ Syafiq Hasyim, Hal-hal yang Tak Terpikirkan tentang isu-isu keperempuanan dalam Islam, h. 202.

${ }^{29}$ Syuhudi Ismail, Hadits Nabi yang Tekstual dan Kontekstual, h. 66.
} 
martabat mereka sebagai makhluk yang bertanggung jawab di hadirat Allah, baik terhadap diri, keluarga dan masyarakat, maupun negara.

Dalam kondisi sosio-historis semacam inilah, sebagaiman yang telah ditulis dalam asbab-al-Wurud, Nabi sebagai orang yang memiliki otoritas dan kearifan menyatakan bahwa bangsa yang menyerahkan kepemimipinannya kepada wanita tidak akan sukses. Sebab bagaimana mungkin akan sukses, jika pemimpinnya saja adalah seorang yang tidak dihargai oleh masyarakatnya. Padahal salah satu syarat ideal seorang pemimpin adalah kewibawaan, disamping mempunyai leadhership yang memadai. Sementara wanita saat itu tidak mempunyai leadhership dan kewibawaan untuk menjadi pemimpin masyarakat. ${ }^{30}$

Oleh sebab itu, jika kondisi historis sosiologis masyarakat berubah, di mana wanita telah memiliki kemampuan memimpin yang baik, dan masyarakat pun telah menghargai wanita dengan baik dan menerimanya sebagai pemimpin, maka sah-sah saja wanita menjadi pemimpin publik (presiden), apalagi mejadi hakim, lurah, camat dan sebagainya. ${ }^{31}$ Pandangan yang melarang perempuan hanya karena melihat aspek keperempuanannya untuk menjadi pemimpin dalam wacana feminisme jelas mencerminkan pandangan yang sangat patriarkhi dan karenanya perlu direkonstruksi, bahkan didekonstruksi sama sekali.

Diakui bahwa salah satu penyebab munculnya tafsir agama yang bias gender adalah karena karya-karya keagamaan pada masa dahulu lebih didomonasi oleh ulama laki-laki. Karenanya, subjektifitas laki-laki menjadi sangat kental. Perempuan pada zaman modern ini, sebagaimana yang diakui oleh kalangan ilmuan, terbukti memiliki kecerdasan dan kemampuan yang tak kalah dengan lakilaki.

${ }^{30}$ Syuhudi Ismail, Hadits Nabi yang Tekstual dan Kontekstual, h. 66.

${ }^{31}$ Said Agil Husin al-Munawwar, Studi Kritis hadits Nabi pendekatan SosioHistoris-Kontekstual Asbab al-Wurud, (Cet. I, Yogyakarta: Pustaka Pelajar, 2001), h. 37. 
Kenyataan historis lain dapat dilihat sebelum datangnya Nabi Muhammad. Pada zaman dahulu menurut informasi al-Qur'an, dinegeri Saba' telah dipimpin oleh seorang ratu bernama Balqis. Ternyata ia mampu dan sukses memimpin negaranya. Ini berarti bahwa hadits di atas, yang secara tersirat melarang perempuan menjadi pemimpin, bukan semata-mata meilhat aspek keperempuanannya, melainkan lebih pada aspek leadhershipnya. Sehingga lakilakipun juga tidak akan sukses untuk memimpin masyarakat jika tidak memiliki leadhership yang baik dan kewibawaan yang memadai. Analisis dan kesimpulan semacam ini juga diperkuat dengan tidak ditemukannya hadits Nabi yang shahih, atau yang secara tegas menjelaskan bahwa pemimpin harus laki-laki.

Dengan melihat kedua pendapat di atas antara kelompok konservatif dengan kelompok liberal-progresif, tampak dengan jelas perbedaan mereka dalam memahami makna hadits tersebut. Secara tekstual, makna hadits itu memang sangat jelas melarang seorang perempuan memangku jabatan kepala Negara. Tetapi kalau dilihat konteks hadits itu ketika disabdakan oleh Nabi, sangat berbeda dengan situasi di zaman sekarang ini. Kebebasan bagi seorang wanita untuk mendapatkan pengajaran, berkarir, dan berkompetisi dengan laki-laki dibuka lebar-lebar. Sehingga sangat memungkinkan bagi siapa saja baik pria maupun wanita untuk memangku jabatan apapun dalam masalah-masalah umum.

Kelompok konservatif hanya melihat aspek kelemahan wanita dalam bentuk fisik dan potensi akal. Padahal dalam kehidupan yang sangat berkembang sekarang ini, walaupun potensi akal yang dimiliki laki-laki itu kuat, tapi bisa saja dikalahkan oleh keinginan wanita dalam meningkatkan potensinya walaupun potensi itu sedikit. Dengan demikian pemberlakuan hadits itu sangat kondisional. Artinya kalau ada pemimpin wanita saat ini tidak mempunyai leadhersipyang baik dan tidak memiliki wibawa di mata rakyatnya, maka tentu saja tidak bias diangkat menjadi pemimpin. Begitu pula laki-laki yang tidak punya leadhership dan wibawa yang baik, juga tidak bisa diangkat menjadi pemimpin. 
Dalam Islam diakui bahwa ada perbedaan biologis antara perempuan dan laki-laki. Akan tetapi, secara tegas Islam melarang menjadikan perbedaan itu sebagai alasan untuk mengutamakan salah satu pihak (laki-laki atau perempuan) dan merendahkan pihak lainnya. Dengan ungkapan lain, Islam mengakui adanya perbedaan, tetapi mengutuk perilaku yang membedakan atau diskriminatif, karena bertentangan dengan prinsip tauhid. Ukuran kemuliaan seorang manusia dihadapan Allah adalah prestasi dan kualitas takwanya, tanpa membedakan jenis kelamin.

\section{Kesimpulan}

Dari pembahasan di atas, yang berkaitan dengan hadits nabi dalam hal kepemimpinan wanita dalam wilayah publik, maka dapat dismpulkan :

a. Hadits tersebut jika dilihat dari ketersambungan sanad, maka hadits tersebut mutthasil. Jika dilihat dari segi kualitas rawi, maka rawinya bisa dikategorikan tsiqah, walaupun ada ulama yang menjarhnya, tapi tidak sampai melemahkan perawi tersebut, dan jika dilihat dari segi kuantitas rawi, maka hadits itu termasuk hadit Ahad.

b. Ulama dalam memahami hadits tersebut, secara umum terbagi dua kubu, ada yang memahami secara tekstual dan ada yang memahami secara kontekstual.

c. Pemimpin yang ideal adalah seorang yang mempunyai sikap leadhersip dan berwibawa tanpa ada perbedaan jenis kelamin.

\section{Daftar Pustaka}

Al-Qu'ran al-Karim

Asqalani, Muhammad Ibnu Ali Ibnu Hajar, Fath al-Bari, Juz VIII, Cet. I, Kairo: Dar al-Hadits, 1998.

------------, Nail al-Authar, Jilid VII, Beirut: Dar al-Fikr, t.th.

CD Room, Barnamij al-Hadits al-Syarif al-Kutub al-Tisah. 
Al-Ghafar, Abdu al-Rasu,Abdul Hasan, Wanita dan gaya hidup Modern, Jakarta: Pustaka Hidayah, 1994.

Hasyim, Syafiq, Hal-hal yang Tak Terpikirkan tentang isu-isu keperempuanan dalam Islam, Cet. II, Bandung: Mizan, 2001.

Ibnu al-Athi, Usd al-Ghaba fi Tamyis al-Sahabah,jilid 5, Dar al-Fikr li al-Tiba wa al-Tawzi, t.th.

Ismail, Syuhudi, Hadits Nabi yang Tekstual dan Kontekstual, Cet. I, Jakarta: Bulan Bintang, 1994.

Ja'far, Muhammad Anis Qasim, Perempuan dan Kekuasaan, terj. Irwan Kurniawan et.al., Cet. I, Bandung: Zaman Wacana Islam, 1998.

Mernissi, Fatima, Menengok Kontroversi peran Wanita dalam Politik, Terj. Oleh Masyhur Abadi Cet, I, Surabaya: Dunia Ilmu, 1997.

Al-Munawwar, Said Agil Husin, Studi Kritis hadits Nabi pendekatan SosioHistoris-Kontekstual Asbab al-Wurud, Cet. I, Yogyakarta: Pustaka Pelajar, 2001.

al-Zahabî, Syamsuddin Muhammad bin Ahmad bin Utsmân, Sîru A'lâm alNubalâ, Juz 10, Cet. VIII, Beirut: Muassasah al-Risalah, 1992. 